\title{
Serological and molecular investigation for brucellosis in swine in selected districts of Uganda
}

\author{
Joseph Erume ${ }^{1} \cdot$ Kristina Roesel $^{2} \cdot$ Michel M. Dione $^{2} \cdot$ Francis Ejobi $^{1}$. \\ Gerald Mboowa $^{3} \cdot$ Joseph M. Kungu $^{2} \cdot$ Joyce Akol $^{2} \cdot$ Danilo Pezo $^{2} \cdot$ Hosny El-Adawy $^{4}$. \\ Falk Melzer ${ }^{4} \cdot$ Mandy Elschner $^{4} \cdot$ Heinrich Neubauer $^{4} \cdot$ Delia Grace $^{5}$
}

Received: 23 October 2015 / Accepted: 19 April 2016/Published online: 3 May 2016

(C) The Author(s) 2016. This article is published with open access at Springerlink.com

\begin{abstract}
Brucellosis is a notifiable zoonotic disease affecting livestock, humans, and wildlife in Uganda. Pigs can be infected with human pathogenic Brucella suis biovars 1 and 3 and can be a significant source of brucellosis for humans. Uganda has a rapidly growing pig population, and the pork consumption per capita is the highest in East Africa. The objective of this work was to determine the seroprevalence of brucellosis in Ugandan pigs. A cross-sectional serosurvey of pigs was conducted in three of the major pig-keeping districts in Uganda (Masaka ( $n=381$ samples), Mukono $(n=398)$, and Kamuli $(n=414)$ ). In addition, pigs originating from these districts were sampled in the major pig abattoir in Kampala $(n=472)$. In total, 1665 serum samples were investigated by serological and molecular tests. Only three putative brucellosis-positive samples were detected serologically using indirect ELISA. These sera were found negative for Brucella antibodies by CFT; however, two had antibodies against Yersinia enterocolitica as determined by SAT. Presence of antibodies against Yersiniae was confirmed by
\end{abstract}

Joseph Erume

erujoseph@yahoo.com

1 College of Veterinary Medicine, Animal Resources and Biosecurity, Makerere University, P. O. Box 7062, Kampala, Uganda

2 International Livestock Research Institute (ILRI), C/O Bioversity International, P. O. Box 24384, Kampala, Uganda

3 Mycobacteriology (BSL-3) Laboratory, College of Health Sciences, Makerere University, P. O. Box 7072, Kampala, Uganda

4 Friedrich-Loeffler-Institute, Federal Research Institute for Animal Health, Institute for Bacterial Infections and Zoonoses, Naumburger Str. 96a, 07743 Jena, Germany

5 International Livestock Research Institute, P. O. Box 30709, Nairobi, Kenya
Y. enterocolitica antibody-specific ELISA. The two Yersiniae ELISA-positive samples were brucellosis negative using real-time PCR. We tested additional 142 sera from the 1665 samples with real-time PCR. All tested negative. Under this type of production system, we expect a maximum $B$. suis prevalence of less than $1 \%$ at $95 \%$ confidence level, and therefore, the risk of acquiring brucellosis from the pigs or their products is negligible. However, pigs may harbor the zoonotic $Y$. enterocolitica. This is the first study to investigate the occurrence of brucellosis in pigs in Uganda and the first study to report $Y$. enterocolitica antibodies in swine in Uganda.

Keywords Screening · Porcine brucellosis · Yersiniosis · Masaka $\cdot$ Mukono $\cdot$ Kamuli districts

\section{Introduction}

Brucellosis is a notifiable zoonotic disease affecting people, livestock, and wildlife globally (Perry and Sones 2007). It is widespread causing significant human suffering and serious economic losses in livestock (Nakavuma and Opuda-Asibo 1999; McDermott et al. 2013). Although national statistics are lacking, there is considerable concern about brucellosis in Uganda. A seroprevalence of 12 and $7 \%$ was reported among beef abattoir workers in Kampala and Mbarara district, respectively (Nabukenya et al. 2013). In Mulago National Refererral Hospital, located in Kampala City, 652 cases of brucellosis were diagnosed between June 2004 and May 2006 alone (Makita et al. 2008).

Brucellosis, caused by Brucella suis, is a major disease of pigs causing infertility, production of small litters, and abortion in sows. B. suis is a notable occupational hazard particularly to abattoir workers, farmers, and veterinarians (Radostits 
et al. 2000; Swai and Schoonman 2012). Uganda has reported pig brucellosis to OIE between 1996 and 2000 (Scientific Opinion of the Panel on Animal Health and Welfare AHAW on a request from the Commission on porcine brucellosis Brucella suis 2009), but it is not clear how this was diagnosed and which strains or biovars were involved. Our literature review found no publications on porcine brucellosis in Uganda, but initial scoping studies with farmers revealed high levels of abortion and infertility (Ouma et al. 2014).

Pig production in Uganda can be categorized into three main systems namely (i) intensive, (ii) semi-intensive, and (iii) extensive (small-scale subsistence). Less than $10 \%$ of pigs are kept in intensive or semi-intensive systems but extensive/tethered/small-scale pig-production system is common (Dione et al. 2014). The demand for pork in Uganda is growing rapidly, and the population of pigs has increased from 0.19 million in 1980 to 3.2 million in 2008 (Uganda Bureau of Statistics/Ministry of Agriculture and Fisheries 2009); currently, Uganda has the largest pig population in eastern Africa and ranks 3rd in sub-Saharan Africa (FAOSTAT/FAO 2011). The prevalence of porcine brucellosis in Uganda is unknown though the disease is present in sub-Saharan Africa (Godfroid et al. 2013; Ducrotoy et al. 2015).

The objectives of this work were to determine the seroprevalence of brucellosis in Ugandan pigs, to assess the brucellosis risk from pigs posed to humans, and to characterize the organisms involved. The work was part of Consultative Group for International Agricultural Research (CGIAR) research aiming at characterizing challenges and evaluating options that will allow emerging pig farmers to improve their productivity and livelihoods, while increasing the supply of critical nutrients to their communities and urban centers.

\section{Methodology}

\section{Study area}

The study was conducted from December 2012 to July 2013 in the only official pig abattoir in Kampala City and in pig farms in Masaka, Mukono, and Kamuli districts, Uganda. The three districts studied were selected using a process to identify district representative of high pork production potential (Ouma et al. 2014).

\section{Abattoir sampling strategy}

A cross-sectional abattoir survey was conducted on pigs brought from three districts of Uganda: Masaka, Mukono, and Kamuli. Visits were made twice a week for a period of 3 months when pigs from the target districts were scheduled for slaughter, and blood samples of at least 20 pigs were taken purposively. The blood was collected into sterile vacutainer tubes without anticoagulant, and metadata for each sample included the district of origin and date the animal was sampled. Blood samples were immediately safely transported in a cold box to the College of Veterinary Medicine, Animal Resources and Biosecurity, Makerere University, where sera were harvested and stored at $-20{ }^{\circ} \mathrm{C}$ until analyzed.

\section{On-farm sampling strategy}

A cross-sectional farm survey was carried out in Masaka, Mukono, and Kamuli districts from April to July 2013. The pig population data from the government livestock census of 2008 was used to facilitate identification of locations within the selected districts where the pig value chain activities would take place. In each district, four to six sub-counties with high pig population were selected for further scrutiny of the existing value chain domains. Three value chain domains were considered: rural production for rural consumption (R$\mathrm{R}$ ), rural production for urban consumption (R-U), and urban/ periurban production for urban consumption (U-U). In a particular district, two sub-counties were selected to represent each value chain domain. Within each selected sub-county, two to three villages were randomly selected for the pig value chain activities. In total, 35 villages were selected for the project value chain assessment activities (Ouma et al. 2014). For this study and due to financial limitations, 22 out of the 35 villages were purposively selected across the three districts. In the selected villages, a census of all pig farmers was provided by local governmental staff and farmer selection was performed using computer-generated, random numbers. The epidemiological unit was considered to be the farm. In each farm, one animal fitting the inclusion criteria was selected and included in the survey. A structured questionnaire was administered to the owner of the farm. The aim of the questionnaire was to assess the disease risk in the farming system. In each household, the selected pig was restrained and blood was collected from the jugular vein into a sterile vacutainer tube without anticoagulant and serum was harvested immediately upon return from the field.

\section{Sample size determination}

The sample size at each site was calculated considering an infinite population (no recent census data) using the formula adopted from Thrusfield (1995) as follows:

$n=Z^{2} P(1-P) / d^{2}$, where $n$ is the required sample size; $Z$ is the multiplier from normal distribution (1.96); $P$ is the estimated prevalence which is $50 \%$ considering the fact that there was no reliable prevalence data for brucellosis in Uganda; (1 $-\mathrm{P})$ is the probability of having no disease and $d$ is the desired precision (5\%). The level of confidence for the study was set at $95 \%$ confidence interval. Based on this formula, a decision was made to sample a total of 384 farms in each district and 
was rounded to 400 . Additional samples were purposively collected from village boars.

\section{Criteria for exclusion}

Piglets younger than 3 months old, pregnant sows and nursing sows with litters less than 2 months old, as well as weak pigs which might be adversely affected by bleeding were excluded from the survey.

\section{Laboratory analysis}

\section{Serological detection of antibodies against Brucella}

Indirect ELISAs Specific detection of antibodies against Brucella in the porcine serum samples was carried out using two indirect ELISA kits: the Ingezim Brucella Porcine Brucella-Ab indirect ELISA kit (INGENASA, Madrid, Spain) and the ID. Vet Screen ${ }^{\circledR}$ (Grabels, France).

\section{Ingezim Brucella Porcine Brucella-Ab indirect ELISA A} total of 472 serum samples from adult pigs slaughtered at the abattoir and 381 collected on farm from Masaka were screened for antibodies against Brucella at Makerere University, College of Veterinary Medicine, Animal Resources and Biosecurity, using Ingezim ELISA according to the manufacturer's instructions. The Ingezim Brucella Porcine Brucella-Ab indirect ELISA kit has a sensitivity of $75 \%$, is highly specific (98\%) (Muñoz et al. 2012), and is based on Brucella LPS antigen. The samples were run on Brucella-Ab indirect ELISA kit and the optical densities (ODs) were determined in a microplate spectrometer (BioTek EL 800, North Star Scientific, Ltd) at 450-nm wavelength. Positive and negative control serum samples were included in each test. Interpretation of the results was based on S/P calculation: $\mathrm{S} / \mathrm{P}=\mathrm{OD}$ sample/OD positive control. Samples with the $\mathrm{S} / \mathrm{P}$ higher than or equal to 0.25 were considered as positive, and all those with $\mathrm{S} / \mathrm{P}$ value less than 0.25 were considered negative.

ID. Vet Screen ${ }^{\circledR}$ ELISA A total of 1193 sera from pigs aged 3 months and older, including village boars, were shipped to Friedrich-Loeffler-Institute (FLI) and screened for antibodies against Brucella using indirect ELISA. Of these sera, 381, 398, and 414 were collected from Masaka, Mukono, and Kamuli, respectively. The sera were screened for antibodies against Brucella using ID. Vet Screen ${ }^{\circledR}$ (ID. Vet Innovative Diagnostics, Grabels, France) according to the manufacturer's instructions. ID. Vet Screen ${ }^{\circledR}$ is a robust test that is based on the purified Brucella LPS antigen. The results by ID Screen ${ }^{\circledR}$ ELISA were validated by testing the field samples in parallel with archived Brucella antibody-positive (14RB6037 FLI, 10RB1462 EUPigBSS) controls, a negative control
(13RB4440 FLI), and positive field samples (08RB3522, 08RB3538 FLI) from the 2008 outbreak of brucellosis in wild boars in Germany.

Complement fixation test The complement fixation test (CFT) was performed as a confirmatory test on putative positive samples identified by indirect ELISA. The CFT was carried out at OIE Reference Laboratory for brucellosis (hosted by FLI) following a micromethod according to the Kolmer technique (fixation at $2-8{ }^{\circ} \mathrm{C}$, overnight) and OIE Terrestial Manual 2012 guidelines. The serum samples and positive and negative controls were first diluted 1:5 with CFTB and incubated in a water bath at $60{ }^{\circ} \mathrm{C}$ for $30 \mathrm{~min}$ to inactivate the complement. Then, in 96-well, U-bottomed microplates, beginning from the second row, $25 \mu$ l of inactivated serum samples was serially diluted in CFTB from 1:5 to $1: 320$, after which $25 \mu$ of brucellosis antigen (IDEXX Pourquier (France) (diluted 1:100 with CFTB)) was added to each well, followed by addition of $25 \mu \mathrm{l}$ of complement (VIRION, Germany) to each well at working dilution 1:55 in CFTB. Control wells with diluent only, complement and diluent and antigen, and complement titrations $2,1,0.5$, and 0.25 , with diluent and antigen, were prepared to contain $75 \mu \mathrm{l}$ in each well. The plates were shaken briefly and incubated for 16-20 h in a refrigerator. The plates after overnight incubation were pre-warmed in the incubator at $30^{\circ} \mathrm{C}$ for $30 \mathrm{~min}$. Then $50 \mu \mathrm{l}$ of freshly prepared hemolytic system was added into each well and plates were shaken carefully. The plates were incubated at $37{ }^{\circ} \mathrm{C}$ for $15-30 \mathrm{~min}$ in a wet chamber. The plates were centrifuged for $5 \mathrm{~min}$ at $1000 \times g$. The degree of hemolysis was compared with set standards corresponding to $0,25,50,75$, and $100 \%$ lysis. The absence of anticomplementary activity was checked for each serum in the first row of the plates. Results were expressed in CFT international units (ICFTU) per millimeter calculated in line with those obtained in parallel titration with national standard serum calibrated against OIE International Standard Serum which contains 595 ICFTU/ml (OIE Terrestial Manual 2012). Sera giving a titer of $20 \mathrm{ICFTU} / \mathrm{ml}$ or more were considered to be positive.

Slow agglutination test Slow agglutination to detect agglutinating antibodies against Yersinia enterocolitica was performed in U-bottomed microtiter plates as previously described (Burkhardt 1992). The serum samples were serially diluted twofold using $0.005 \%$ solution of safranin in phosphate-buffered saline. Then an equal volume $(50 \mu \mathrm{l})$ of $Y$. enterocolitica 0:9 standardized antigen (YAG 03/09) prepared from ATCC 55075 reference strain (FLI, Jena, Germany) was added to each well. The plates were shaken on a shaker and incubated in a wet chamber in the 
incubator at $37^{\circ} \mathrm{C}$ for $20-24 \mathrm{~h}$. Test sera were analyzed in parallel with Brucella-positive (KS Bruc 03/04) and Brucella-negative (KS Bruc 03/04) control sera and $Y$. enterocolitica weak and strong positive sera. After incubation, agglutination titers were determined and expressed as the reciprocal of the final dilution in which agglutination was observed. The results were evaluated as follows: for negative, occurrence of a clear red button/ knob of antigen at the bottom; for positive, evaluated according to the degree of agglutination thus (1) film without red center-4+, (2) film with small red center$3+$, (3) film with moderate red center-2+, (4) film with intensive/strong red center-1+, and (5) clear red button at bottom- 0 .

Indirect ELISA for $\boldsymbol{Y}$. enterocolitica antibodies Indirect ELISA using PIGTYPE ${ }^{\circledR}$ YOPSCREEN test kit (Qiagen ${ }^{\circledR}$ GmbH, Hilden, Germany) was used to detect antibodies to pathogenic Yersiniae in the pig sera that were positive by SAT. The test was performed according to the manufacturer's instructions. The results were validated by testing the Uganda samples in parallel with archived Y. enterocolitica antibodypositive field samples (13RB4901 FLI, 13RB4902 FLI, and 13RB4903FLI).

\section{Molecular detection of Brucella}

DNA preparation from sera DNA was extracted and purified from porcine serum using DNeasy Blood and Tissue Kit (QIAGEN, Germany) according to the instructions of the manufacturer using QIAcube. The DNA concentration was determined photometrically using a Nano Drop ND-1000 UV-vis spectrophotometer (Nano-Drop Technologies, Wilmington, USA).

Real-time PCR Multiplex real-time PCR was used for detection of the genus-specific Brucella cell surface salt extractable bcsp31 kDa protein gene, Brucella abortus alkB gene and Brucella melitensis BMEI1162 gene from extracted DNA (Probert et al. 2004). The B. abortus and B. melitensis TaqMan probes target the alkB and BMEI1162 gene, respectively. PCR reaction was performed using primer and probe set is shown in Table 1 (Jena Bioscience GmbH, Germany). The $25 \mu \mathrm{l}$ multiplex PCR mixture consisted of $2 \times$ TaqMan $^{\mathrm{TM}}$ Environmental master mix (Applied Biosystems, NJ USA), $200 \mathrm{nM}$ of each primer, $100 \mathrm{nM}$ of each probe, and $5 \mu \mathrm{l}$ of template DNA. Amplification and real-time fluorescence detection was performed on a Mx3000P thermocycler system (Stratagene, La Jolla, Canada) using the following reaction conditions: 2 min denaturation at $50{ }^{\circ} \mathrm{C}$, polymerase activation step at $95{ }^{\circ} \mathrm{C}$ for $10 \mathrm{~min}$, followed by 50 cycles of $95{ }^{\circ} \mathrm{C}$ for $25 \mathrm{~s}$ and $57{ }^{\circ} \mathrm{C}$ for $1 \mathrm{~min}$. The samples scored positive were confirmed by visual inspection of the graphical plots showing cycle numbers versus fluorescence values. A sample with a fluorescence signal 30 times greater than the mean standard deviation in all wells over cycles 2 through 10 was considered a positive result, whereas a sample yielding a fluorescence signal less than this threshold value was considered a negative result. Cycle threshold values below 40 cycles were interpreted as positive.

Since age has been alluded to as a significant risk factor for bovine brucellosis (Muñoz et al. 2012), we performed realtime PCR on almost all $(86.57 \%, n=58)$ "village boar" samples. Additionally, ELISA positive and other sera, amounting to $12 \%$ of 1193 on farm serum samples, were tested by realtime PCR.

\section{Data analysis}

Standard statistical analyses were performed using Microsoft Office Excel 2010. The disease prevalence
Table 1 Oligonucleotide primers and probes used in the real-time multiplex PCR assay for the detection of Brucella spp., B. abortus, and B. melitensis

\begin{tabular}{lll}
\hline Target & Primer & \\
\hline Brucella spp. & 5'GCTCGGTTGCCAATATCAATGC 3' & Forward \\
& 5'GGGTAAAGCGTCGCCAGAAG 3' & Reverse \\
B. abortus & FAM-AAATCTTCCACCTTGCCCTTGCCATCA-BHQ1 & Probe \\
& 5'GCGGCTTTTCTATCACGGTATTC 3' & Forward \\
& 5'CATGCGCTATGATCTGGTTACG 3' & Reverse \\
B. melitensis & HEX-CGCTCATGCTCGCCAGACTTCAATG-BHQ1 & Probe \\
& 5'AACAAGCGGCACCCCTAAAA 3' & Forward \\
& 5'CATGCGCTATGATCTGGTTACG 3' & Reverse \\
& CY5-CAGGAGTGTTTCGGCTCAGAATAATCCACA-BHQ2 & Probe \\
\hline
\end{tabular}

FAM carboxyfluorescein, HEX hexachlorofluorescein, BHQ1 Black Hole Quencher 1, BHQ2 Black Hole Quencher 2 
was calculated by dividing the number of positive samples by the total number of samples tested. Test sensitivity (Se) of $75 \%$ and specificity (Sp) of $98 \%$ for i-ELISA (Muñoz et al. 2012) were used to calculate apparent prevalence of antibodies against Brucella infection according to Greiner and Gardner (2000).

\section{Results}

\section{Abattoir seroprevalence of porcine brucellosis}

Of the 472 serum samples tested, 332, 2, and 138 sera were collected from pigs originating from Masaka, Mukono, and Kamuli districts, respectively. None of the serum samples was positive for Brucella antibodies, indicating $0 \%$ apparent abattoir prevalence (95\% CI: 0.008 ) of porcine brucellosis in the three districts, suggesting absence of active Brucella exposure.

\section{On-farm seroprevalence of porcine brucellosis}

A total of $1(0.28 \%), 0(0 \%)$, and $1(0.25 \%)$ serum samples were putatively seropositive for Brucella in Masaka, Mukono, and Kamuli districts, respectively (Table 2). The positive sample from Masaka was detected by Ingezim ELISA and that from Kamuli by ID. Vet Screen ${ }^{\circledR}$. There was no agreement between the results of the two tests on Masaka samples. The Ingezim ELISA kit was not employed for testing samples from Mukono and Kamuli districts.
Table 2 Seroprevalence of porcine brucellosis in Masaka, Mukono, and Kamuli districts as detected by indirect ELISA

\begin{tabular}{|c|c|c|c|c|c|}
\hline \multirow[t]{2}{*}{ District } & \multirow[t]{2}{*}{ Village } & \multirow[t]{2}{*}{ Sub-county } & \multirow{2}{*}{$\begin{array}{l}\text { Number } \\
\text { samples }^{\mathrm{a}}\end{array}$} & \multicolumn{2}{|c|}{ Number brucellosis positive ${ }^{\mathrm{b}}$} \\
\hline & & & & $\begin{array}{l}\text { Makerere (Ingezim } \\
\text { porcine iELISA) }\end{array}$ & $\begin{array}{l}\text { FLI (ID. Vet } \\
\text { Screen iELISA) }\end{array}$ \\
\hline \multirow[t]{9}{*}{ Masaka } & Kisoso & Kkingo & $43(2)$ & 1 & 0 \\
\hline & Ssenya & Kkingo & $34(0)$ & 0 & 0 \\
\hline & Lukindu & Kyanamukaka & $37(0)$ & 0 & 0 \\
\hline & $\begin{array}{l}\text { Kanoni- } \\
\text { Bukunda }\end{array}$ & Kyanamukaka & $50(1)$ & 0 & 0 \\
\hline & Senyange A & $\begin{array}{l}\text { Ivan } \\
\text { Kakembo }\end{array}$ & $50(0)$ & 0 & 0 \\
\hline & $\begin{array}{l}\text { Kyamuyimbwa } \\
\text { Kikalala }\end{array}$ & Kabonera & $35(0)$ & 0 & 0 \\
\hline & Butego & $\begin{array}{l}\text { Katwe- } \\
\text { Butego }\end{array}$ & $27(0)$ & 0 & 0 \\
\hline & Kijjabwemi & $\begin{array}{l}\text { Kimanya- } \\
\text { Kyabakuza }\end{array}$ & $43(0)$ & 0 & 0 \\
\hline & Kyabakuza B & $\begin{array}{l}\text { Kimanya- } \\
\text { Kyabakuza }\end{array}$ & $35(0)$ & 0 & 0 \\
\hline \multirow[t]{7}{*}{ Mukono } & Kazo/Kalagala & Tenjeru & $52(1)$ & $\mathrm{Nd}$ & 0 \\
\hline & Nsanja/Gonve & Tenjeru & $43(0)$ & $\mathrm{Nd}$ & 0 \\
\hline & Bugoye/Kabira & Tenjeru & $48(0)$ & $\mathrm{Nd}$ & 0 \\
\hline & Kyoga & Kyampisi & $52(0)$ & $\mathrm{Nd}$ & 0 \\
\hline & Dundu & Kyampisi & $61(0)$ & $\mathrm{Nd}$ & 0 \\
\hline & Kitete & Mukono TC & $55(0)$ & $\mathrm{Nd}$ & 0 \\
\hline & Joggo & Mukono TC & $64(0)$ & $\mathrm{Nd}$ & 0 \\
\hline \multirow[t]{6}{*}{ Kamuli } & Balubweneiwa & Bugulumbya & $46(0)$ & $\mathrm{Nd}$ & 0 \\
\hline & Bukyonza B & Bugulumbya & $30(0)$ & $\mathrm{Nd}$ & 0 \\
\hline & Butabala & Kitayunjwa & $40(0)$ & $\mathrm{Nd}$ & 0 \\
\hline & Isingo A & Namwendwa & $70(0)$ & $\mathrm{Nd}$ & 0 \\
\hline & Ntansi & Butansi & $105(0)$ & $\mathrm{Nd}$ & 1 \\
\hline & Kantu zone & Butansi & $110(0)$ & $\mathrm{Nd}$ & 0 \\
\hline Total & 22 & & $1130(4)$ & 1 & 1 \\
\hline
\end{tabular}

Nd not done

${ }^{a}$ In brackets are the number of village boars sampled from each village as part of random sample

${ }^{\mathrm{b}}$ Sites where samples were tested 


\section{Brucellosis status among purposively sampled village boars}

Overall, 63 samples from purposively sampled village boars were analyzed; of these, 27, 25, and 13 were from Masaka, Mukono, and Kamuli, respectively. In total, 0 (0.0\%), 0 (0\%), and $1(7.69 \%)$ serum samples were putatively seropositive for Brucella in Masaka, Mukono, and Kamuli districts, respectively, as detected by ID. Vet Screen ${ }^{\circledR}$ (Table 3).

\section{Testing of samples with complement fixation test}

For confirmation, the two samples that presumptively tested positive by indirect ELISA (ID. Vet Screen ${ }^{\circledR}$ ) were subjected to CFT analysis at FLI. Sera were tested in parallel with FLI Brucella antibody strong positive (14RB7378) and weak positive (14RB7379) samples. Both putatively positive samples from Ugandan swine tested negative for Brucella antibodies by CFT.

\section{Ugandan pigs positive for antibodies against $Y$. enterocolitica}

To check if the detected antibodies were due to crossreactivity to $Y$. enterocoltica, the two putative positive samples were subjected to slow agglutination test for $Y$. enterocolitica 0:9 antibodies. Both samples from Uganda (14RB7097 and 14RB7324) tested positive for $Y$. enterocolitica antibodies by slow agglutination test, with titers of 40/2 and 40/3, respectively, indicating a $0.17 \%$ prevalence of $Y$. enterocolitica antibodies in the pigs tested. To confirm their serological status, these samples were tested for Y. enterocolitica antibodies by
Table 3 Porcine brucellosis in purposively sampled village boars from Masaka, Mukono, and Kamuli districts as detected by indirect ELISA

\begin{tabular}{|c|c|c|c|c|c|}
\hline \multirow[t]{2}{*}{ District } & \multirow[t]{2}{*}{ Village } & \multirow[t]{2}{*}{ Sub-county } & \multirow{2}{*}{$\begin{array}{l}\text { Number of } \\
\text { village boar } \\
\text { samples }\end{array}$} & \multicolumn{2}{|c|}{ Number brucellosis positive ${ }^{a}$} \\
\hline & & & & $\begin{array}{l}\text { Makerere (Ingezim } \\
\text { porcine iELISA) }\end{array}$ & $\begin{array}{l}\text { FLI (ID. Vet } \\
\text { Screen iELISA) }\end{array}$ \\
\hline \multirow[t]{9}{*}{ Masaka } & Kisoso & Kkingo & 2 & $\mathrm{Nd}$ & 0 \\
\hline & Ssenya & Kkingo & 5 & $\mathrm{Nd}$ & 0 \\
\hline & Lukindu & Kyanamukaka & 1 & $\mathrm{Nd}$ & 0 \\
\hline & $\begin{array}{l}\text { Kanoni- } \\
\text { Bukunda }\end{array}$ & Kyanamukaka & 4 & $\mathrm{Nd}$ & 0 \\
\hline & Senyange A & $\begin{array}{l}\text { Ivan } \\
\text { Kakembo }\end{array}$ & 3 & $\mathrm{Nd}$ & 0 \\
\hline & $\begin{array}{l}\text { Kyamuyimbwa } \\
\text { Kikalala }\end{array}$ & Kabonera & 8 & $\mathrm{Nd}$ & 0 \\
\hline & Butego & $\begin{array}{l}\text { Katwe- } \\
\text { Butego }\end{array}$ & 1 & $\mathrm{Nd}$ & 0 \\
\hline & Kijjabwemi & $\begin{array}{l}\text { Kimanya- } \\
\text { Kyabakuza }\end{array}$ & 2 & $\mathrm{Nd}$ & 0 \\
\hline & Kyabakuza B & $\begin{array}{l}\text { Kimanya- } \\
\text { Kyabakuza }\end{array}$ & 1 & $\mathrm{Nd}$ & 0 \\
\hline \multirow[t]{7}{*}{ Mukono } & Kazo/Kalagala & Tenjeru & 8 & $\mathrm{Nd}$ & 0 \\
\hline & Nsanja/Gonve & Tenjeru & 4 & $\mathrm{Nd}$ & 0 \\
\hline & Bugoye/Kabira & Tenjeru & 0 & $\mathrm{Nd}$ & 0 \\
\hline & Kyoga & Kyampisi & 2 & $\mathrm{Nd}$ & 0 \\
\hline & Dundu & Kyampisi & 2 & $\mathrm{Nd}$ & 0 \\
\hline & Kitete & Mukono TC & 3 & $\mathrm{Nd}$ & 0 \\
\hline & Joggo & Mukono TC & 4 & $\mathrm{Nd}$ & 0 \\
\hline \multirow[t]{6}{*}{ Kamuli } & Balubweneiwa & Bugulumbya & 2 & $\mathrm{Nd}$ & 0 \\
\hline & Bukyonza B & Bugulumbya & 1 & $\mathrm{Nd}$ & 0 \\
\hline & Butabala & Kitayunjwa & 1 & $\mathrm{Nd}$ & 1 \\
\hline & Isingo A & Namwendwa & 0 & $\mathrm{Nd}$ & 0 \\
\hline & Ntansi & Butansi & 9 & $\mathrm{Nd}$ & 0 \\
\hline & Kantu zone & Butansi & 0 & $\mathrm{Nd}$ & 0 \\
\hline Total & 22 & & 63 & & 1 \\
\hline
\end{tabular}

$N d$ not done

${ }^{\text {a }}$ Sites where samples were tested 
indirect ELISA using PIGTYPE $^{\circledR}$ YOPSCREEN kit (Qiagen ${ }^{\circledR} \mathrm{GmbH}$, Hilden, Germany). One sample (14RB7097) tested positive while the other (14RB7324) was negative.

\section{Testing of serum samples with real-time PCR}

To confirm the absence of Brucella infection, the $Y$. enterocolitica-positive sample and 143 other sera from Uganda [that comprised of 58 samples from boars $(86.57 \%$ of all boars), and 45 and 40 randomly selected sera that showed higher and low ODs in indirect ELISA, respectively, representing $12.07 \%(n=144)$ of the total serum samples] were tested for brucellosis using real-time PCR. The other $Y$. enterocolitica-positive sample could not be tested by realtime PCR due to lack of serum. No Brucella-specific DNA signal was detected in all samples tested.

\section{Statistical analysis}

Considering sample size to detect disease for infinite population: $n=\ln ($ alpha $) / \ln (1-p)$, where $p=$ the minimum prevalence, and if assuming the $p$ to be $5 \%$ then $n=\ln (0.05) /$ $\ln (0.95)=58.4$. This work analyzed 1130 randomly collected samples, so reversing the equation $\ln ($ alpha $) / n=\ln (1-p)$ gives

$$
\begin{gathered}
\ln (\text { alpha }) / n=\ln (1-p) \\
\ln (1-p)=\ln (0.05) / 1130=-0.00265 \\
p=1-(\exp (-0.00265))=1-0.9973=0.0027 .
\end{gathered}
$$

Therefore, the sample size used in this study was sufficient to find the disease if it was present in $0.27 \%$ of the population.

Assuming a perfect test $(\mathrm{Se}=1)$, the prevalence in the population must be maximum of $0.27 \%$ for us not to have found it in 1130 samples. The Ingezim Brucella Porcine Ab i-ELISA shows a sensitivity of $75 \%$; therefore, the prevalence will be no higher than $0.81 \%$.

\section{Discussion}

To our knowledge, this is the first study to investigate the occurrence of brucellosis in pigs in Uganda or other East African countries. None of the sera tested was positive for porcine brucellosis. Under this type of production system, we expect a maximum $B$. suis prevalence of less than $1 \%$ at $95 \%$ confidence level. Since this study included pigs from Mukono and Masaka, two of the districts with the highest density of pigs in Uganda, and failed to detect disease there, it is likely to be absent.

Our findings that Brucella antibodies were absent from a large and representative sample of pigs in the major pig- producing districts of Uganda are consistent with earlier reports of $0 \%$ (Cadmus et al. 2006) and $0.6 \%$ (Onunkwo et al. 2011; Nwanta et al. 2011) prevalence of porcine brucellosis in Nigeria. A $0 \%$ prevalence was also found in commercial piggeries in Zambia (Stafford et al. 1992). Our results however differed from those of Ngbede et al. (2013) who reported a high seroprevalence of porcine brucellosis (30.6\%) in Benue State, Nigeria. All the serological studies reporting the occurrence of porcine brucellosis in Nigeria used RBT for testing whereas our study employed multiple tests. RBT reportedly has high sensitivity (100\%) but is less specific (84\%) (Akhtar et al. 2010).

The finding of $0.17 \%$ prevalence of $Y$. enterocolitica antibodies in our study population is of public health significance. $Y$. enterocolitica is an important zoonotic agent of global concern (Bhaduri et al. 2005; Ifeoma 2013) that can cause serious human suffering ranging from fever, abdominal pain, diarrhea to more serious complications such as appendicitis and erythema nodosum (Bari et al. 2011). Pigs are reported to be the main reservoir of these organisms (Adesiyun and Krishnan 1995; Bhaduri et al. 2005; Fredriksson-Ahomaa et al. 2010). To the best of our knowledge, this is the first report on the occurrence of $Y$. enterocolitica exposure in Ugandan pigs and calls for research on the infection and risks associated with this pathogen. Further studies are needed to investigate the prevalence and impact of $Y$. enterocolitica on Ugandan pigs and to investigate other causes for the high reported levels of abortion and infertility in pigs.

Acknowledgments The field research was funded by the Consultative Group for International Agricultural Research (CGIAR) Research Program on Agriculture for Nutrition and Health and the "Safe Food, Fair Food" project (funded by the Federal Ministry for Economic Cooperation and Development, Germany) in cooperation with the CGIAR Research Program on Livestock and Fish through the "Smallholder Pig Value Chains Development" project in Uganda (funded by IFAD-EU). Additional funding was provided by the German Academic Exchange Service (DAAD) through an in-region post-doctoral fellowship in partnership with the International Livestock Research Institute (ILRI), The World Academy of Sciences (TWAS)/German Research Foundation (DFG), and the Friederich-Loeffler-Institute (FLI), Germany. We would like to thank Dr Jane Poole (ILRI) and Dr Ian Dohoo (Prof. em. University of Prince Edward Island, Canada) for advice on the statistical analysis. Moreover, our appreciation goes to Uta Pfeil, Michaela Ganss, and Angella Musewa for technical assistance and Dr. Francis Mutebi and the veterinary officers at Wambizzi Cooperative Society Ltd. for their assistance and cooperation during abattoir sampling. We extend our utmost appreciation to the field veterinary staff and farmers in Masaka, Mukono, and Kamuli districts for the assistance and support during on-farm sample collection.

Authors' contribution DG, KR, and MD (ILRI, Kenya) designed and coordinated the study; KR and MD (ILRI, Uganda) participated in project design, data interpretation, and manuscript preparation. DP (ILRI, Uganda) participated in conceptualizing the study and manuscript preparation. FE (Makerere University) was involved in study design and planning. JK and JA (ILRI, Uganda) participated in design and field sampling. GM (Makerere University, College of Health Sciences) was involved in 
laboratory analysis. HE, FM, ME, and HN (Friedrich Loeffler Institute) contributed new laboratory analysis, data analysis and helped to draft and review the manuscript. JE (Makerere University) made conceptual contributions, involved in the study design, sample collection, sample examination, analysis, and writing of the manuscript. All authors read and approved the final version of the manuscript.

\section{Compliance with ethical standards}

Conflict of interest The authors declare that they have no conflict of interest.

Ethical clearance This work involved animal sampling and interviewing of farmers. Ethical clearance was obtained from the Ethical Review Committee of the College of Veterinary Medicine, Animal Resources and Biosecurity, Makerere University (No. VAB/ REC/13/101) and ILRI Institutional Research Committee (Ref. IREC 2013-03). The farmers were duly informed about the study and their written consent was sought prior to the start of data collection.

Open Access This article is distributed under the terms of the Creative Commons Attribution 4.0 International License (http:// creativecommons.org/licenses/by/4.0/), which permits unrestricted use, distribution, and reproduction in any medium, provided you give appropriate credit to the original author(s) and the source, provide a link to the Creative Commons license, and indicate if changes were made.

\section{References}

Adesiyun, A.A. and Krishnan C., 1995. Occurrence of Yersinia enterocolitica 0:3, Listeria monocytogenes 0:4 and thermophilic Campylobacter spp. in slaughter pigs and carcasses in Trinidad. Food Microbiology, 12(2), 99-107

Akhtar, R., Chaudhry, Z.I., Shakoori, A.R., Mansoor ud Din, A. and Aslam, A., 2010. Comparative efficacy of conventional diagnostic methods and evaluation of polymerase chain reaction for the diagnosis of bovine brucellosis. Veterinary World, 3(2), 53-56

Bari, L., Hossain, M.A., Isshiki, K. and Ukuku, D.O., 2011. Behavior of Yersinia enterocolitica in Foods. Journal of Pathogens. doi: 10.4061/ 2011/420732.

Bhaduri, S., Wesley, I.V. and Bush, E.J., 2005. Prevalence of Pathogenic Yersinia enterocolitica Strains in Pigs in the United States. Applied and Environmental Microbiology, 71(11), 7117-7121

Burkhardt, F., 1992. Mikrobiologische Diagnostik(Georg Thieme Verlag Stuttgart-New York)

Cadmus, S.I.B., Ijagbone, I.F., Oputa, H.E., Adesokan, H.K. and Stack, J.A., 2006. Serological survey of Brucellosis in Livestock Animals and Workers in Ibadan, Nigeria. African Journal of Biomedical Research, 9, 163-168

Dione, M.M., Ouma, E.A., Roesel, K., Kungu, J., Lule, P. and Pezo, D., 2014. Participatory assessment of animal health and husbandry practices in smallholder pig production systems in three high poverty districts in Uganda. Preventive Veterinary Medicine, 117(3-4), 565-576

Ducrotoy, M., Bertu, W.J., Matope, G., Cadmus, S., Conde-Álvarez, R., A.M. Gusi, A.M., Welburn, S., Ocholi, R., Blasco, J.M. and Moriyón, I., 2015. Brucellosis in Sub-Saharan Africa: Current challenges for management, diagnosis and control. Acta Tropica. doi:10. 1016/j.actatropica.2015.10.023

FAOSTAT/FAO, 2011. Food Balance/Food Supply - Livestock and Fish Primary Equivalent. Retrieved January 5, 2016, from http://faostat3. fao.org/browse/FB/CL/E.
Fredriksson-Ahomaa, M., Meyer, C., Bonke, R., Stüber, E. and Wacheck, S., 2010. Characterization of Yersinia enterocolitica 4/O:3 isolates from tonsils of Bavarian slaughter pigs. Letters in Applied Microbiology, 50(4), 412-418

Godfroid, J., Al Dahouk, S., Pappas, G., Roth, F., Matope, G., Muma, J., Marcotty, T., Pfeiffer, D. and Skjerve, E., 2013. A "One Health" surveillance and control of brucellosis in developing countries: moving away from improvisation. Comparative Immunology, Microbiology and Infectious Diseases, 36(3), 241-248

Greiner, M. and Gardner, I.A., 2000. Application of diagnostic tests in veterinary epidemiologic studies. Preventive Veterinary Medicine, 45(1-2), 43-59

Ifeoma, M.M., 2013. Incidence and Public Health Significance of Yersinia enterocolitica in Enugu Urban-Enugu State, Nigeria. Journal Of Environmental Science, Toxicology And Food Technology, 6(3), 52-56

Makita, K., Fèvre, E.M., Waiswa, C., Kaboyo, W., De Clare Bronsvoort, B.M., Eisler, M.C. and Welburn, S.C., 2008. Human brucellosis in urban and peri-urban areas of Kampala, Uganda. Annals of the New York Academy of Sciences, 1149, 309-311

McDermott, J., Grace, D. and Zinsstag, J., 2013. Economics of brucellosis impact and control in low-income countries. Revue scientifique et techniquecpcOffice International des Epizooties, 32(1), 249-261

Muñoz, P.M., Blasco, J.M., Engel, B., de Miguel, M.J., Marín, C.M., Dieste, L. and Mainar-Jaime, R.C., 2012. Assessment of performance of selected serological tests for diagnosing brucellosis in pigs. Veterinary Immunology and Immunopathology, 146(2), 150-158

Nabukenya, I., Kaddu-Mulindwa, D. and Nasinyama, G.W., 2013. Survey of Brucella infection and malaria among Abattoir workers in Kampala and Mbarara Districts, Uganda. BMC Public Health. 13: 901. doi: 10.1186/1471-2458-13-901

Nakavuma, J.K. and Opuda-Asibo, J., 1999. Sero study of Brucella abortus in cattle and goat in central and southern Uganda. Uganda Journal of Agricultural Sciences, 4, 13-18

Ngbede, E.O., Momoh, A.H., Ruben Sylvester Bala, R.S., Madaki, B.D. and Maurice, N.A., 2013. An Abattoir-Based Study on Serodiagnosis of Swine Brucellosis in Makurdi, Benue State, North-Central Nigeria. Journal of Advanced Veterinary Research, 3(2), 57-59

Nwanta, J. A., Shoyinka, S.V.O., Chah, K.F., Onunkwo, J.I., Onyenwe, I.W., Eze, J.I., Iheagwam, C. N., Njoga, E.O., Onyema, I., Ogbu, K.I., Mbegu, E.C., Nnadozie, P.N., Ibe E.C. and Oladimeji, K.T. (2011). Production characteristics, disease prevalence, and herdhealth management of pigs in Southeast Nigeria. Journal of Swine Health and Production, 19(6), 331-339

Onunkwo, J.I., Njoga, E.O., Nwanta, J.A., Shoyinka, S.V.O., Onyenwe, I.W. and Eze J.I., 2011. Serological Survey of Porcine Brucella Infection in South East, Nigeria. Nigerian Veterinary Journal, 32(1), 60-62

Ouma, E., Dione, M., Lule, P., Roesel, K. and Pezo, D., 2014: Characterization of smallholder pig production systems in Uganda: constraints and opportunities for engaging with market systems. Livestock Research for Rural Development, 26(3), Article \#56. Retrieved January 5, 2016, from http://www.lrrd.org/lrrd26/3/ ouma26056.htm

Perry, B. and Sones, K., 2007. Poverty reduction through animal health. Science, 315 (5810), 333-334, doi: 10.1126/science.1138614

Probert, W.S., Schrader, K.N., Khuong, N.Y., Bystrom, S.L. and Graves, M.H., 2004. Real-time Multiplex PCR Assay for Detection of Brucella spp., B. abortus, and B. melitensis. Journal of Clinical Microbiology, 42(3), 1290-1293

Radostits, O.M., Gay, C.C., Blood, D.C., and Hinchcliff, K.W., 2000. Veterinary Medicine: A textbook of the diseases of cattle, sheep, pigs, goats and horses. (W.B. Saunders Company Ltd, New York)

Scientific Opinion of the Panel on Animal Health and Welfare (AHAW) on a request from the Commission on porcine brucellosis (Brucella suis)., 2009. The EFSA Journal, 1144, 1-112. Retrieved January 5, 
2016 from http://www.efsa.europa.eu/sites/default/files/scientific output/files/main_documents/1144.pdf

Stafford, K., Tafford, Y., Paton, D. and Gamble, P., 1992. Antibodies to some swine disease in commercial piggeries in Central Zambia. Revue d'élevage et de médecine vétérinaire des pays tropicaux, 45(3-4), 229-230

Swai, E.S. and Schoonman, L., 2012. A survey of zoonotic diseases in trade cattle slaughtered at Tanga city abattoir: a cause of public health concern. Asian Pacific Journal of Tropical Biomedicine, 2(1), 55-60

OIE Terrestial Manual, 2012. Chapter 2.4.3. Bovine brucellosis, 616-650 Thrusfield, M., 1995. Veterinary Epidemiology. Blackwell Science Ltd, Oxford.

Uganda Bureau of Statistics/Ministry of Agriculture, Animal Industry \& Fisheries, 2009. A summary report of the livestock census, 2008. 